\title{
Isolated Memory Loss in Anti-NMDAR Encephalitis
}

Raffaele Iorio, MD, PhD, Eleonora Sabatelli, MD, Lucia Campetella, MD, and Claudia Papi, MD

Neurol Neuroimmunol Neuroinflamm 2022;9:e1128. doi:10.1212/NXI.0000000000001128

\section{Abstract}

\section{Background and Objectives}

To report a case of anti-NMDAR encephalitis presenting with isolated memory dysfunction.

\section{Methods}

A 29-year-old woman was admitted to the Neurology Department referring memory impairment with a subacute onset. The initial assessment included EEG, neuropsychological tests, and brain MRI. Serum and CSF samples were collected for immunologic studies. The diagnostic evaluation was completed with a total body PET scan.

\section{Results}

Patient's neurologic examination was unremarkable apart from an episodic memory deficit, confirmed by neuropsychological examination. The EEG revealed epileptiform discharges in the temporal lobes, whereas brain MRI showed bilateral temporal lobes hyperintense lesions on fluid-attenuated inversion recovery images and T2-weighted images. NMDAR-IgG was detected in the patient's serum and CSF by cell-based assay confirming the diagnosis of definite anti-NMDAR encephalitis. The total body PET showed only a slight hypometabolism in the right temporal cortex and in the cerebellar hemispheres. After a course of IV immunoglobulin and corticosteroid therapy, a marked improvement of the memory deficit was observed.

\section{Discussion}

This case shows that anti-NMDAR encephalitis can present with isolated memory loss. Neural antibody testing in these patients could play a pivotal role in early diagnosis and prompt treatment.

\author{
Correspondence \\ Dr. Iorio \\ raffaele.iorio@policlinicogemelli.it
}



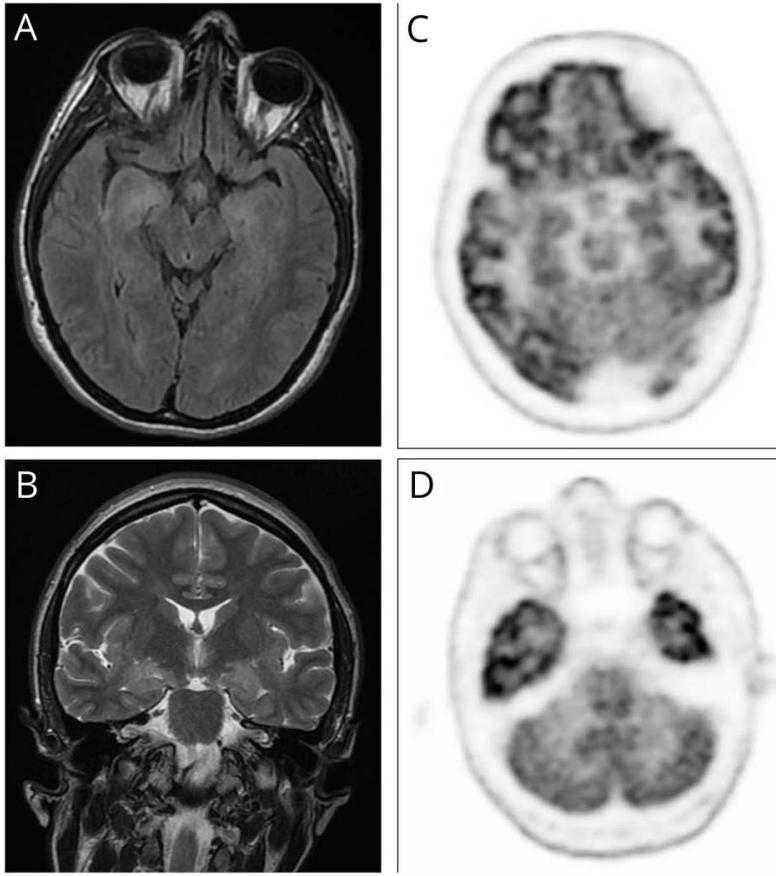
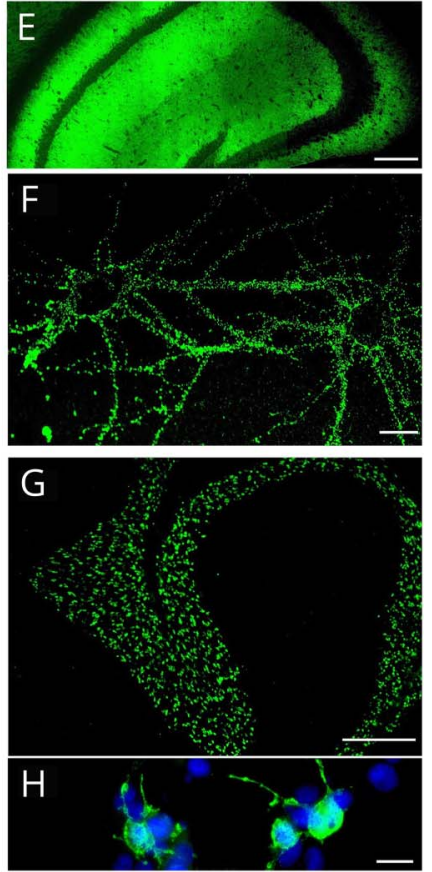

Brain MRI showing bilateral hyperintense lesions on fluid-attenuated inversion recovery images (A) and T2-weighted images (B) involving the hippocampi and the mesial portion of the temporal lobes. Brain PET imaging showing slight hypometabolism of the right temporal lobe (C) and a more pronounced hypometabolism of the cerebellar hemispheres (D). Indirect immunofluorescence assays showing the binding of IgG from the patient's CSF to the neuropil of the mouse hippocampus (E), nonfixed/ nonpermeabilized rat hippocampal neurons $(F)$, the granular layer of the mouse cerebellum (G), and HEK293 cells expressing NMDA receptor $(H)$. Nuclei are stained with 4',6-diamidino-2-phenylindole.
The clinical features of autoimmune encephalitis (AE) associated with immunoglobulin $\mathrm{G}$ ( $\mathrm{IgG}$ ) autoantibodies binding to NMDA receptor (NMDAR) usually differ from the classic limbic encephalitis and may vary among patients and age groups. Anti-NMDAR encephalitis is usually a multistage illness that progresses from psychosis, memory deficits, seizures, and speech dysfunction to movement disorders, coma, and central hypoventilation. ${ }^{1}$ A monosymptomatic syndrome has been rarely described in patients with psychiatric symptoms, seizures, ${ }^{2}$ or movement disorders. ${ }^{3}$ We report a patient with anti-NMDAR encephalitis presenting with isolated memory impairment.

\section{Standard Protocol Approvals, Registrations, and Patient Consents}

The study was approved by the UCSC Ethic Committee. A signed informed consent form was obtained from the patient's parents.

\section{Case Report}

At the end of February 2021, a 29-year-old woman started to experience a decrease in job performance while working as remote employee $8 \mathrm{~h} / \mathrm{d}$. During that time, the patient's husband noticed that her ability of remembering new information was markedly impaired. In the following days, the memory disorder progressively worsened, with exacerbation in moments of emotional distress, in which she could not remember events occurred even in the previous minute. The patient was not aware of her amnesia. She lost her job and her social life. However, she did not experience anxiety, depression, or any psychotic symptoms. One month after the onset of memory loss, the patient was admitted to our institution.

Eight years before admission, the patient underwent surgery for ovary mucinous cystadenoma. Her medical history was otherwise unremarkable. Neurologic examination revealed only an episodic memory deficit without other signs or symptoms. The Mini-Mental State Examination revealed an impaired delayed recall (final score: 27/30). Laboratory investigations on admission were normal. The EEG revealed epileptiform discharges in the temporal lobes, but the patient never experienced seizures. A 24-hour EEG did not reveal any seizure activity. Neuropsychological examination showed a severe isolated deficit of verbal and visual episodic memory. Brain MRI revealed hyperintense lesions on fluid-attenuated inversion recovery (FLAIR) and T2-weighted images involving both temporal lobes (Figure, A and B). CSF analysis showed mild pleocytosis and the presence of oligoclonal bands. NMDAR-IgG was detected in the patient's serum and CSF by cell-based assay and confirmed by other indirect immunofluorescence assays (Figure, E-H). Ultrasound and MRI of the pelvis were normal. A total body PET showed a slight hypometabolism in the right temporal cortex and in the cerebellar hemispheres (Figure, C and D).

The patient was treated with IV immunoglobulins $0.4 \mathrm{~g} / \mathrm{kg} /$ $\mathrm{d}$ for 5 days and oral prednisone $25 \mathrm{mg} / \mathrm{d}$. Another course of IVIG was administered to the patient after 3 months. A brain MRI performed 4 months after the admission showed the persistence of $\mathrm{T} 2$ hyperintense lesions in the temporal lobes. At the last follow-up, 7 months after the onset, the patient still 
in therapy with prednisone $10 \mathrm{mg} / \mathrm{d}$ presented a marked improvement of the memory deficit (MMSE score: 30/30). The patient remembered most of the recent events occurred over the last 2 months, and she was aware of her improvement in everyday life. She had not returned to work yet, but she regained her social life.

\section{Discussion}

This case with isolated memory impairment as an initial symptom highlights an unusual monosymptomatic presentation of anti-NMDAR encephalitis. In patients with $\mathrm{AE}$ associated with NMDAR-IgG, memory impairment usually occurs during the disease course, but, to the best of our knowledge, it has been reported in association with psychiatric disturbances, seizures, movement disorders, and/or impairment of other cognitive domains. We cannot exclude that the patient might have developed other neurologic symptoms if she had not received immunotherapy, but the persistence of the isolated memory deficit is noteworthy. The current diagnostic criteria for the $\mathrm{AE}$ diagnosis mostly rely on clinical characteristics and neuroimaging. ${ }^{4}$ The patient herein described fulfilled the diagnostic criteria of limbic encephalitis, but before neural antibody testing, she could have not been diagnosed with antiNMDAR encephalitis according to the current criteria. AntiNMDAR encephalitis is a severe disease and may require an aggressive therapeutic approach. Early diagnosis and the prompt initiation of appropriate immunotherapy are critical for patients' outcome. ${ }^{5}$ Of interest, PET imaging showed hypometabolism of the right temporal lobe and the cerebellar hemispheres. The patient did not have any signs or symptoms of cerebellar dysfunction, but the PET imaging findings suggest a possible cerebellar involvement. NMDAR-IgG binds to granular cells in the cerebellum, ${ }^{6}$ but cerebellar ataxia has been rarely described in anti-NMDAR encephalitis. ${ }^{7}$

In sum, this case shows that anti-NMDAR encephalitis can present with isolated memory loss associated with neuroimaging and electroencephalographic features characteristic of limbic encephalitis. Neural antibody testing can be critical to perform an accurate diagnosis in patients with $\mathrm{AE}$.

\section{Study Funding}

No targeted funding reported.

\section{Disclosure}

The authors have no conflicts of interest. Go to Neurology.org/NN for full disclosures.

\section{Publication History}

Received by Neurology: Neuroimmunology \& Neuroinflammation September 17, 2021. Accepted in final form November 2, 2021.

Appendix Authors

\begin{tabular}{|c|c|c|}
\hline Name & Location & Contribution \\
\hline $\begin{array}{l}\text { Raffaele } \\
\text { Iorio, MD, } \\
\text { PhD }\end{array}$ & $\begin{array}{l}\text { UOC Neurologia, } \\
\text { Fondazione Policlinico } \\
\text { Universitario A. Gemelli } \\
\text { IRCCS, Rome, Italy; } \\
\text { Università Cattolica del } \\
\text { Sacro Cuore, Rome, Italy }\end{array}$ & $\begin{array}{l}\text { Drafting/revision of the } \\
\text { manuscript for content, } \\
\text { including medical writing for } \\
\text { content; major role in the } \\
\text { acquisition of data; study } \\
\text { concept or design; and } \\
\text { analysis or interpretation of } \\
\text { data }\end{array}$ \\
\hline $\begin{array}{l}\text { Eleonora } \\
\text { Sabatelli, } \\
\text { MD }\end{array}$ & $\begin{array}{l}\text { Università Cattolica del } \\
\text { Sacro Cuore, Rome, Italy }\end{array}$ & $\begin{array}{l}\text { Major role in the acquisition } \\
\text { of data }\end{array}$ \\
\hline $\begin{array}{l}\text { Lucia } \\
\text { Campetella, } \\
\text { MD }\end{array}$ & $\begin{array}{l}\text { Università Cattolica del } \\
\text { Sacro Cuore, Rome, Italy }\end{array}$ & $\begin{array}{l}\text { Major role in the acquisition } \\
\text { of data }\end{array}$ \\
\hline $\begin{array}{l}\text { Claudia } \\
\text { Papi, MD }\end{array}$ & $\begin{array}{l}\text { Università Cattolica del } \\
\text { Sacro Cuore, Rome, Italy }\end{array}$ & $\begin{array}{l}\text { Drafting/revision of the } \\
\text { manuscript for content, } \\
\text { including medical writing for } \\
\text { content, and major role in the } \\
\text { acquisition of data }\end{array}$ \\
\hline
\end{tabular}

\section{References}

1. Dalmau J, Gleichman AJ, Hughes EG, et al. Anti-NMDA-receptor encephalitis: case series and analysis of the effects of antibodies. Lancet Neurol. 2008;7(12): 1091-1098.

2. Niehusmann P, Dalmau J, Rudlowski C, et al. Diagnostic value of N-methyl-Daspartate receptor antibodies in women with new-onset epilepsy. Arch Neurol. 2009; 66(4):458-464.

3. Rubio-Agustí I, Dalmau J, Sevilla T, Burgal M, Beltrán E, Bataller L. Isolated hemidystonia associated with NMDA receptor antibodies. Mov Disord. 2011;26(2): 351-352.

4. Graus F, Titulaer MJ, Balu R, et al. A clinical approach to diagnosis of autoimmune encephalitis. Lancet Neurol. 2016;15(4):391-404.

5. Iorio R, Damato V, Spagni G, et al. Clinical characteristics and outcome of patients with autoimmune encephalitis: clues for paraneoplastic aetiology. Eur J Neurol. 2020; 27(10):2062-207.

6. Iorio R, Assenza G, Tombini M, et al. The detection of neural autoantibodies in patients with antiepileptic-drug-resistant epilepsy predicts response to immunotherapy. Eur J Neurol. 2015;22(1):70-78.

7. Poorthuis MHF, van Rooij JLM, Koch AH, Verdonkschot AEM, Leembruggen MM, Titulaer MJ. Cerebellar ataxia as a presenting symptom in a patient with anti-NMDA receptor encephalitis. Neurol Neuroimmunol Neuroinflamm. 2019;6(4):e579. 


\section{Neurology \\ Neuroimmunology \& Neuroinflammation}

Isolated Memory Loss in Anti-NMDAR Encephalitis Raffaele Iorio, Eleonora Sabatelli, Lucia Campetella, et al.

Neurol Neuroimmunol Neuroinflamm 2022;9;

DOI 10.1212/NXI.0000000000001128

This information is current as of December 22, 2021

Updated Information \& Services

References

Subspecialty Collections

Permissions \& Licensing

Reprints including high resolution figures, can be found at: http://nn.neurology.org/content/9/2/e1128.full.html

This article cites 7 articles, 1 of which you can access for free at: http://nn.neurology.org/content/9/2/e1128.full.html\#\#ref-list-1

This article, along with others on similar topics, appears in the following collection(s):

Autoimmune diseases

http://nn.neurology.org//cgi/collection/autoimmune_diseases

Information about reproducing this article in parts (figures,tables) or in its entirety can be found online at:

http://nn.neurology.org/misc/about.xhtml\#permissions

Information about ordering reprints can be found online: http://nn.neurology.org/misc/addir.xhtml\#reprintsus

Neurol Neuroimmunol Neuroinflamm is an official journal of the American Academy of Neurology.

Published since April 2014, it is an open-access, online-only, continuous publication journal. Copyright

Copyright (C) 2021 The Author(s). Published by Wolters Kluwer Health, Inc. on behalf of the American Academy of Neurology.. All rights reserved. Online ISSN: 2332-7812.

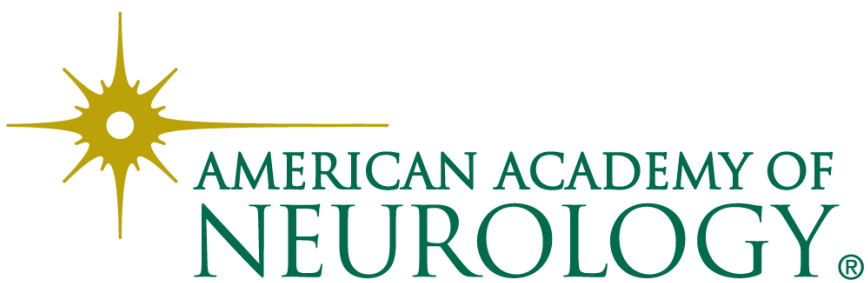

